\title{
PANDANGAN AL-BUTHI TERHADAP HUKUM MENGIKUTI PROGRAM KELUARGA BERENCANA (KB) BERDASARKAN INTERVENSI NEGARA
}

\author{
Moh. Mufid \\ UIN Sunan Kalijaga \\ Yogyakarta \\ moh.mufid@uin- \\ suka.ac.id
}

\begin{abstract}
This article aims to discuss al-Buthi's thoughts about the law following a family planning program on state intervention. The family planning program is claimed as one of the strategies to reduce birth rates to avoid high population growth rates. On the other hand, one of the aims of marriage in Islam is to give birth to offspring who can be the successor and prosperity of the earth. Therefore, family planning programs in this context are seen as blocking this noble goal. Al-Buthi, one of the contemporary scholars, has a very dichotomous thought. This study shows that al-Buthi is of the view that family planning law over state intervention for his people is an act that is not in line with the purpose of marriage. That is why, according to al-Buthi the law is haram. Unlike the law, if both husband and wife couples carry out family planning programs through azl or other contraceptives without any intervention from any party, including from the state, then it is permissible as long as the husband and wife's consent and the existence of benefits that are personal to both. The basic thought of al-Buthi is the qiyasi reasoning and the maqasidi reasoning.
\end{abstract}

Keywords: Intervention, country, family planning, al-Buthi.

\begin{abstract}
Abstrak: Artikel ini bertujuan untuk mengkaji pemikiran al-Buthi tentang hukum mengikuti program keluarga berencana atas intervensi negara. Program keluarga berencana diklaim sebagai salah satu strategi untuk menekan angka kelahiran untuk menghindari tingkat pertumbuhan penduduk yang tinggi. Di pihak yang lain, tujuan pernikahan dalam Islam salah satunya adalah untuk melahirkan keturunan yang dapat menjadi penerus dan pemakmur bumi. Oleh karena itu, program keluarga
\end{abstract}




\begin{abstract}
berencana dalam konteks ini dianggap menghalangi tujuan mulia ini. Al-Buthi salah satu ulama kontemporer memiliki pemikiran yang sangat dikotomis. Kajian ini menunjukkan bahwa al-Buthi berpendapat hukum keluarga berencana atas intervensi negara kepada rakyatnya merupakan tindakan yang tidak sejalan dengan tujuan pernikahan. Itu sebabnya, menurut al-Buthi hukumnya haram. Berbeda hukumnya, jika kedua pasangan suami-istri melakukan program KB melalui cara 'azl atau alat kontrasepsi lainnya tanpa adanya intervensi dari pihak manapun, termasuk dari negara maka dibolehkan selama atas persetujuan suami-istri dan adanya kemaslahatan yang bersifat personal bagi keduanya. Dasar pemikiran al-Buthi tersebut adalah nalar qiyasi dan nalar maqasidi.
\end{abstract}

Kata Kunci: Intervensi, negara, keluarga berencana, al-Buthi.

\title{
Pendahuluan
}

Di Indonesia, program keluarga berencana telah dikembangkan sebagai salah satu program nasional sejak zaman era pra reformasi.1 Masalah kependudukan terutama menyangkut pertumbuhan penduduk mengakibatkan meningkatnya kebutuhan hidup untuk melayani perkembangan jumlah penduduk tersebut. Dalam konteks inilah, pemerintah menganjurkan masyarakat untuk mengikuti program keluarga berencana untuk menekan pertumbuhan pendudukan yang sangat cepat dan signifikan.

Secara normatif, dalam Islam perencanaan kelahiran anak dalam suatu keluarga merupakan hak bagi setiap pasangan dalam rumah tangga. Akan tetapi, jika hal itu dilakukan

1Organisasi keluarga berencana dimulai dari pembentukan Perkumpulan Keluarga Berencana pada tanggal 23 Desember 1957 di gedung Ikatan Dokter Indonesia. Nama perkumpulan itu sendiri berkembang menjadi Perkumpulan Keluarga Berencana Indonesia (PKBI) atau Indonesia Planned Parenthood Federation (IPPF). PKBI memperjuangkan terwujudnya keluarga- keluarga yang sejahtera melalui 3 macam usaha pelayanan yaitu mengatur kehamilan atau menjarangkan kehamilan, mengobati kemandulan serta memberi nasihat perkawinan. Lihat, https://www.bkkbn.go.id/pages/sejarah-bkkbn diakses 10 Mei 2020. 
berdasarkan intervensi pihak luar hukumnya bisa berbeda. Dalam konteks ini, al-Buthi memberikan analisis yang argumentatif dalam merespon hukum mengikuti program tersebut berdasarkan intervensi pihak pemerintah demi menyeimbangkan angka kelahiran dan pengendalilan jumlah penduduk. Perspektif yang berbeda ini menarik untuk dikaji lebih jauh dan mendalam sehingga mendapat perspektif baru tentang hukum program keluarga berencana.

Sosok al-Buthi adalah satu satu intelektual kontemporer yang menjadi rujukan dalam islamic studies. Minimal ada dua hal yang menjadikan al-Buthi sebagai rujukan dalam kajian keislaman deawasa ini. Pertama, al-Buthi adalah sosok ulama yang komplit dari sisi pengetahuannya. Hal ini dapat dirujuk pada karya-karya al-Buthi yang sangat beragam. Hampir berbagai diskursus kajian keislaman tidak luput menjadi perhatiannya dan ia berhasil memberikan kontribusinya dalam merespon dinamika pemikiran kontemporer.

Kedua, al-Buthi salah satu fāqih yang mampu mendialogkan khazanah turats Islam dengan dinamika perkembangan kontemporer. Perubahan zaman yang terjadi secara cepat dan signifikan memberikan dampak yang massif dalam munculnya problematika di tengah-tengah masyarakat. Pada titik ini, al-Buthi merupakan pioner dalam merespon masalah hukum Islam kontemporer. Itu sebabnya, banyak bukubukunya yang merupakan jawaban atas persoalan-persoalan tersebut.

Kajian tentang al-Buthi sebenarnya sudah banyak dilakukan. Abdul Mukit misalnya, telah mengkaji pemikiran alButi dari aspek pendidikan akidah. Kajian Mukit menunjukkan bahwa pendidikan akidah yang ditawarkan al-Buthi adalah pendidikan akidah yang bersifat responsif, solutif, dan ilmiah yang sangat relevan untuk diaktualisasikan dalam kontek pendidikan Islam kontemporer.2

Mujiati dan Hakim juga mengkaji pemikiran al-Buthi di bidang dakwah. Secara spesifik, artikel yang dipublikasikan

2Abdul Mukit, "Pendidikan Akidah: Telaah Pemikiran Muhammad Sa'id Ramadan al-Buthi”, Jurnal Tawazun, Vol. 8 No. 1 (Januari-Juni 2015), 1-25. 
pada Jurnal Mediakita ini mengkaji buku al-Buthi yang berjudul "Hākadha falnad'u Ila al-Islām. Kesimpulan artikelnya menunjukkan bahwa al-Buthi sebagai ulama yang moderat dalam berdakwah. Dakwah harus mencerminkan kesantunan, perdamaian dan bersikap moderat terhadap doktrin agama. 3

Kajian seputar pemikiran al-Buthi dalam istinbath hukum kontemporer telah dilakukan oleh Abdul Basith. Dalam artikelnya, ia berkesimpulan bahwa al-Buthi diklaim sebagai sosok ulama kontemporer yang mendasarkan penlaran hukumnya pada prinsip al-mașlaḥah. Bahkan, ia diktegorikan sebagai tokoh aliran religious utilitarianisme. Secara konseptual, al-Buthi berhasil merumuskan rambu-rambu dalam mengaplikasikan konsep al-mașlahah dalam merumuskan hukum Islam.4

Jauh sebelum Basith, penulis sendiri telah melakukan kajian mendalam tentang pemikiran al-Buthi yang telah dipublikasikan dalam bentuk buku berjudul Nalar Ijtihad Fiqh Muhammad Sa'id Ramdahan al-Buthi.s Penelitian ini merupakan tesis yang diujikan pada tahun 2013 lalu. Selanjutnya, pada tahun 2019, penulis mempublikasikan artikel yang berjudul Kontribusi Muhammad Sa'id Ramadhan Al-Buthi dalam Pemikiran Hukum Publik Islam.6 Kedua karya penulis tersebut, belum menyentuh pemikiran al-Buthi dalam bidang hukum program keluarga berencana secara spesifik.

Dalam konteks inilah, kajian pemikiran al-Buthi sebagai wacana diskursus pemikiran dalam dinamika intelektual Muslim menjadi urgen untuk ditelaah lebih jauh. Terlebih, sosok al-Buthi sebagai pemikir kontemporer telah melahirkan banyak

3Nanik Mujiati dan Lukman Hakim, "Pemikiran al-Buthi tentang Problematika Dakwah", Jurnal Mediakita, Vol. 3, No. 1 (Januari 2019), 21-42.

4Abdul Basith, "Konsep Istinbat Hukum Kontemporer Menurut Muhammad Sa'id Ramdhan al-Buthi, Jurnal Studi Islam dan Muamalah at-Tahdzib, Vol. 7, No. 2 (2019), 45-61

5Lihat, Moh. Mufid, Nalar Ijtihad Fiqh Muhammad Sa'īd Ramadhān al-Būthi (Banjarmasin: Antasari Press, 2013).

6Moh. Mufid, "Kontribusi Muhammad Sa'id Ramadhan Al-Buthi dalam Pemikiran Hukum Publik Islam", Al-Jinayah: Jurnal Hukum Pidana Islam, Vol 4 No 1 (Juni 2018). 
karya di bidang hukum Islam. Salah satu karya yang relevan dengan kajian ini adalah Mas'alah Tahdìd al-Nasl Wiqāyah wa 'Ilājān. Oleh sebab itu, penelusuran pemikiran al-Buthi tentang topik ini akan dilakukan dari beberapa karyanya yang memiliki relevansi dengan kajian hukum keluarga Islam.

Artikel ini akan menjawab dua persoalan yang seringkali menjadi diskursus dalam kajian hukum Islam, khsusunya hukum keluarga Islam. Bagaimana pandangan al-Buthi tentang hukum mengikuti program Keluarga Berencana (KB) sebab intervensi negara? bagaimana nalar epistemologis yang menjadi pijakan pandangan al-Buthi?. Maka dari itu, fokus utama kajian ini diarahkan pada deskripsi pandangan al-Buthi tentang hukum program keluarga berencana sebab intervensi negara dan nalar epistemologisnya.

\section{Karir Akademik dan Intelektual al-Buthi}

Nama lengkap al-Buthi adalah Muhammad Sa'id Ramadhan ibn Mulla Ramadhan ibn Umar al-Buthi. Beliau dilahirkan di desa Jilika, wilayah pulau Buthan, perbatasan Turki dan Irak pada tahun 1929 M.7 Al-Buthi dididik di keluarga yang sangat religius. Bahkan, ayah al-Buthi adalah seoarang ulama sufi terkemuka di Syam yang bergelar Syaikh Mulla Ramadhan al-Buthi.

Karir akademik al-Buthi dimulai sejak dibimbing langsung oleh ayahnya. Sejak kecil al-Buthi belajar ilmu-ilmu alat kepada sang ayah. Nazham Alfiyah Ibn Malik sebagai menu kesehariannya. Bahkan, al-Buthi berhasil menghafalkan baitbait Alfiah dengan waktu yang tidak terlalu lama. Di usianya yang masih sangat muda, al-Buthi juga sudah menghatamkan alQuran.8

Pendidikan selanjutnya, al-Buthi belajar di sekolah swasta setingkat Ibtidaiyah di dekat suq Sarujah. Di bawah bimbingan Syaikh Hasan Habnnakah di salah satu Ma'had al-Taujih alIslamy, al-Buthi melanjutkan studinya. Meskipun demikian, al-

7Muhammad Sa'id Ramadhan al-Buthi, Hādhā Wālidi:al-Qișșah al-Kāmilah li Hayāt al-Syekh Mulla Ramaḍān Al-Būìi min Wilādatih ila Wafātih, cet. IX (Damaskus: Dar al-Fikr, 2006),14. 8Ibid, 56. 
Buthi tetap istikamah untuk melanjutkan belajar di bawah bimbingan ayahnya sendiri. Itu sebabnya, al-Buthi selalu menyempatkan dirinya untuk pulang ke rumah setiap Selasa untuk menimba ilmu Nahwu dan Balaghah kepada sang ayah. Berkat bimbingan sang ayah, al-Buthi berhasil menghafal Uqūd al-Jumān salah satu karya Imam al-Suyuti.

Pendidikan sarjananya ditempuh di negeri kinanah, Mesir. Al-Buthi menyelesaikan S-1 di al-Azhar University pada Fakultas Syariah pada tahun $1955 \mathrm{M}$. Tidak puas dengan sampai di situ, al-Buti selanjutnya mengambil magister di fakultas Sastra Arab di almamater yang sama dan berhasil diselesaikan pada tahun $1956 \mathrm{M}$.

Setelah bergelar master, al-Buti kembali ke Damaskus untuk mengabdikan dirinya di dunia pendidikan. Hingga akhirnya, beliau sempat menjadi guru di salah satu madrasah tenaga pengajar. Karena ketika itu, Kementerian Pendidikan mengada-kan perlombaan kualifikasi untuk calon guru agama, beliaupun disarankan oleh teman-temannya untuk mengikutinya. Tetapi al-Bûthi menolak hal itu, karena beliau tahu, sang ayah tidak mungkin menyetujuinya. Ternyata justru sebaliknya, sang ayah memberikan dukungan penuh kepada anaknya, untuk turut berpartisipasi dalam kompetisi tersebut, dan akhirnya beliau pun berhasil menjadi pemenangnya.

Pada tahun 1961 M, al-Buthi kembali ke Mesir untuk melanjutkan studinya jenjang doktor. Al-Buthi mengambil konsentrasi di bidang fikih dan ushul fikih. Jenjang doktoralnya ditempuh selama empat tahun, sehingga pada tahun 1965M, alButhi sudah bergelar doktor dengan predikat Mumtāz Syaraf Ula". Bahkan, disertasi al-Buthi yang berjudul Dawābit alMașlahah fi al-Sharīah al-Islāmiah mendapat rekomendasi dari al-Azhar untuk diterbitkan dan dipublikasikan sebagai penelitian yang monumental.9

Setelah merampungkan program doktornya, pada tahun 1965 M., al-Bûthi kemudian menjadi dosen tetap mengampu

9Jasim Muhammad al-Mutawwi', Hadis al-Dzikrayat ma'a Fadhilah al-Syaikh Muhammad Said Ramadhan al-Buti, (https://www.youtube.com/watch?v=A5nmSE00zRw) diakses 2 April 2020. 
mata kuliah hukum perbandingan (al-fiqh al-islāmy al-muqārin) dan studi agama (al-aqā'id wa al-adyāân) di kampus yang sama. Pada tahun 1975 M. al-Bûthi diangkat menjadi Guru Besar di bidang kajian fikih lintas mazhab (al-fiqh al-muqārin). Hingga puncaknya, pada tahun 1977 M. al-Buthi menjabat sebagai Dekan Fakultas Syariah. Sejak tahun 2002 M. hingga sebelum wafat, beliau menjabat sebagai Direktur Kajian Teologi dan Agama di Universitas Damaskus Syiria dan sebagai Ketua Persatuan Ulama Syam.

Sebagai seorang ulama Muslim terkemuka, karya alButhi sangat banyak dan beragam. Beliau salah satu ulama kontemporer yang sangat produktif dalam melahirkan karyakarya ilmiah di berbagai disiplin ilmu pengetahuan. Menurut Andreas Christmann, hampir tidak mungkin melihat batasan topik dalam karya-karya al-Buthi. Sebagai sarjana Muslim yang memiliki kedudukan intelektual tinggi dalam kehidupan akademis dan kehidupan publiknya, beliau juga seorang tokoh agama terkemuka dalam perdebatan intelektual dalam Islam mengenai kehidupan modern, al-Buthi menyusun buku tentang semua topik yang relevan dan paling eksplosif pada saat ini.10

Karya-karya al-Buthi yang pernah beliau terbitkan lebih dari 60 judul buku.11 Adapun yang secara spesifik membahas topik ini adalah berjudul Mas'alah Taḥdìd al-Nasl Wiqāyah wa Ilajja $\bar{a} "$. Karya ini ditulis al-Buthi sebagai respon terhadap seminar ilmiah yang bertema "Aborsi Antara hukum Syariat, Medis dan Qanun" di Hamah pada tahun 1984. Secara konten alButhi menjelaskan hukum pencegahan kehamilan melalui

10Ibid, 58.

11Berikut karya beliau yang laris manis di pasaran dan diminati para pengkaji keislaman, di antaranya: Fiqh as-Sirah an-Nabawiyyah (Beirut: Dar al-Fikr, 2003), Kubraal-Yaqiniyat al-Kauniyyah (Beirut: Dar al-Fikr, 2005), Al-Hubb fi al-Qur'ān wa Dauruhu fi Hayāt al-Insān (Beirut: Dar al-Fikr, 2008), La Ya'tīhi al-Bāțil (Beirut: Dar al-Fikr, 2006), Al-Insān Musayyar am Mukhayyar (Beirut: Dar al-Fikr, 2000), As-Salafiyyah Marhalah Tārikhiyyah Mubārakah wa Laisa Madhhaban Islāmiyyan (Beirut: Dar al-Fikr, 2002), Al-Lāmadhhabiyyah Akhtharu Bid'atin Tuhaddidu as-Sharī'ah al-Islämiyyah (Damaskus: Dar-alFarabi, 2008). Al-Mar'ah baina Thughyān an-Niz̄ām al-Gharb wa Lațāif atTashrī’al-Islāmy (Beirut: Dar al-Fikr, 2005). 
Tindakan medis (aborsi) dan penecegahan kehamilan melalui alat kontrasepsi atau melalui proses `azl.

Karya al-Buthi lain, yang merupakan respon terhadap dinamika pemikiran kontemporer dituangkan dalam bukunya berjudul, Qaḍ̄yā Fiqhiyyah Mu'āṣirah, tiga jilid (Damaskus: Daral-Farabi, 2006). Sementara respon al-Buthi tentang doktrin jihad, ia kemudian menulis buku berjudul Al-Jihād fi al-Islām Kaifa Nafhamuhu wa Numārisuhu (Beirut: Dar al-Fikr, 2003). Sebagai ulama yang pakar dibidang sastra, al-Buthi menulis novel berjudul Mamūzain: Qișșh al-Hubb an-Nabāt fi al-Arḍi wa Aynā'a fi al-Samā' (Beirut: Dar al-Fikr, 2001) dan buku yang berisi esai-esai sastra berjudul Min al-Fikr wa al-Qalb (Beirut: Dar al-Fikr, 2008). Adapun buku fenomenalnya di bidang sufistik adalah buku yang berjudul Al-Hikām al-Atā'iyyah Sharhu wa Taḥlīl, lima jilid (Beirut: Dar al-Fikr, 2004).

Demikianlah ragam buku yang telah diterbitkan al-Buthi selama kiprah intelektualnya dalam kapasitasnya sebagai ulama kontemporer. Karya-karya beliau tidak hanya dinikmati di Timur Tengah, tetapi karya beliau telah banyak dikaji di benua Eropa dan Asia. Hal ini tidak lain, karena karya-karya beliau telah banyak diterjemahkan kedalam berbagai bahasa asing, seperti bahasa Inggris, Prancis, Jerman, Malaysia dan Indonesia.

Terkait atas semangatnya ini, al-Buthi mengemukakan dalam bukunya yang berjudul Al-Lā Madhhabiyyah Akhtaru Bid'atin Tuhaddidu as-Sharī'ah al-Islāmiyyah, beliau mengatakan demikian12:

"Saya bertanya pada diri sendiri, apa yang membuat saya tetap menulis dan menulis? Kalau untuk kemasyhuran, saya telah mendapatkan lebih dari yang saya harapkan. Kalau untuk kesejahteraan dan kekayaan, Allah menganugerahkan saya lebih daripada yang saya butuhkan. Dan kalau untuk dihormati orang, saya sudah memperoleh lebih dari yang layak saya terima. Pada akhirnya saya menyadari bahwa semua keinginan yang

12Muhammad Sa'id Ramadhan Al-Buthi, al-Lā Madhhabiyah, Akhtar Bid'ah Tuhaddid al-Syarīah al-Islāmiyah, edisi revisi (Damaskus: Dār al-Farabi, 2005), 193. 
saya sebut tadi sia-sia dan hampa kecuali seuntai doa yang dihadiahkan kepada saya oleh seorang Muslim yang tidak saya kenal."

Al-Buthi wafat pada malam Jumat, 9 Jumadil Awwal 1434 $\mathrm{H}$ bertepatan pada 21 Maret 2013 di Masjid Al-Iman Damaskus dalam peristiwa tragis bombunuh diri oleh kelompok ekstrimis di Syiria. Peristiwa ini terjadi saat al-Buthi sedang menyampaikan pengajian tafsir rutin mingguan di masjid tersebut. Jumlah korban dalam peristiwa bom bunuh diri tersebut mencapai 52 orang meninggal (syahid) termasuk cucu al-Buthi yang bernama Ahmad serta puluhan korban luka-luka lainnya.

Setahun pasca wafatnya al-Buthi, kasus bom bunuh diri tersebut terungkap. Ternyata dalang pembunuhan al-Buthi dilakukan oleh pendukung oposisi (Jabhat Nusrah) salah satu front garis keras di Syiria. Motif pembunuhannya, karena alButhi dianggap sebagai ulama yang aling aktif mengkritik pihak oposisi dan menolak upaya revolusi di Syiria dengan cara kudeta kekuasaan Presiden Bassar al-Assad.

\section{Sakralitas Hubungan Perkawinan dan Maqasid Syariah}

Ikatan perkawinan dalam al-Qur'an disebut sebagai ikatan yang kuat dan suci (mithāqan ghalizah). Kata mithāqan ghalīzah dalam al-Qur'an ditemukan hanya pada tiga tempat. Pertama, pada QS al-Ahzab [33]:7, kedua, QS al-Nisa[4]:154 dan ketiga, QS al-Nisa [4]: 21. Pada bagian pertama, kata mithāqan ghalīzah digunakan untuk menunjukkan perjanjian Allah dengan sejumlah Nabi. Sementara pada QS. Al-Nisa [4]: 154 kata tersebut digunakan untuk menunjukkan perjanjian Allah dengan orang Yahudi. Pada bagian terakhir, kata mithāqan ghalizah dalam QS al-Nisa [4]: 21 digunakan untuk menunjukkan perjanjian perkawinan (nikah). Dalam konteks ini, secara tidak langsung, ungkapan mithāqan ghalīzah dapat disimpulkan bahwa kesucian ikatan perkawinan antara suami- 
istri diumpamakan dengan kesucian hubungan Allah dengan para Nabi dan Rasul-Nya.13

Al-Qur'an juga telah merumuskan tujuan dalam pernikahan. Minimal ada tiga tujuan umum dari perkawinan yang diamanatkan al-Qur'an. Pertama, saran reproduksi dalam rangka tujuan untuk pengembang-biakan umat manusia di muka bumi. Hal ini dapat ditemukan misalnya dalam QS. AlSyura[42: 11, QS al-Rum [30]: 21, QS al-Thalaq [86]: 6-7, QS. AlNisa [4]:1. Tujuan kedua dalam pernikahan adalah pemenuhan kebutuhan seksual, yang dapat dilihat dalam QS al-ma'arij [70]:29-31, QS al-Mu'minun [23]: 5-7, QS al-Baqarah [2]: 187, 223 dan QS al-Nur [24]:33. Sementara tujuan ketiga adalah memperoleh ketenangan, cinta pasangan, dan kasih sayang. Ini dapat dilihat dari QS. Al-Rum [30]: 21.

Pada titik ini, bahwa perkawianan dalam Islam merupakan ikatan atau hubungan yang suci dan sakral antara kedua pasangan yang saling membutuhkan dan melengkapi satu sama lain. Tujuan ikatan perkawinan tidak lain untuk mendapatkan keturunan demi meneruskan generasi umat manusia, memenuhi nafsu seksual, dan menciptakan keluarga yang harmonis, penuh cinta dan kasih sayang.

Terkait dengan sakralitas ikatan perkawianan ini, al-Buti bertolak pada penafsiran dan pemahaman secara konprehensif atas QS al-Nisa [4]: 1. Menurut al-Buti, bahwa ayat tersebut sejatinya bukan hanya ditujukan kepada umat Islam semata, tetapi berlaku bagi semua umat manusia. Hal ini karena hubungan suami-istri merupakan sarana untuk melanggengkan peradaban umat manusia di bumi.

Lebih lanjut, menurut al-Buti, bahwa dalam ayat tersebut Allah menyandingkan perintah takut kepada Allah juga takut kepada al-arhām. Term al-arhām yang ada di dalam al-Qur'an yang dimaksud di sini adalah keluarga. Dari sini, Allah seakanakan hendak mengingatkan kepada umat manusia yang

${ }_{13}$ Gatot Suherman, "Poligami Kaum Elit Agama Islam: Menimbang Plus-Minus Praktik Poligami Kaum Elit Agama bagi Masyarakat", Istinbath: Jurnal Hukum Islam, Vol. 12, No. 2 (Desember 2013), 151. 
berkeluarga untuk tidak mensia-siakan keluarganya dimana dari keluarga itulah umat manusia dapat berkembang-biak dan melanjutkan generasi sebagai pemakmur bumi.14

Oleh karena itu, QS. al-Nisa[4]: 1 tidak ditujukan secara khusus pada umat tertentu. Tetapi, Allah tujukan kepada umat manusia seluruhnya lintas agama, etnik dan budaya. Karena perkawinan sebagai media untuk melanjutkan keturunan tidak hanya dalam tradisi Islam semata, tetapi semua agama dan etnik sama-sama memiliki doktrin yang sama, bahwa pernikahan sebagai sarana melanggengkan eksistensi umat manusia di bumi dari generasi ke generasi. Inilah sebabnya ayat di atas menggunakan ungkapan, ya ayyuha al-nās, bukan ya ayyuha almu'min.15

Secara konseptual, ulama membagi maqasid perkawinan menjadi dua bagian: maqāșid așliyah dan maqāșid tabā'iyah. Maqāṣid așliyah berarti tujuan utama Islam dalam pensyariatan dalam hukum keluarga itu sendiri. Dalam hal ini, tujuan utama Islam dalam perkawinan adalah al-tanāsul (reproduksi/berketurunan). Reproduksi sebagai tujuan dalam pernikahan merupakan upaya untuk menghasilkan keturunan untuk melanjutkan generasi dan tongkat estafet dalam mengemban tugas manusia sebagai khalifah di bumi.

Sementara maqāșid tabāiyyah merupakan tujuan Islam yang bersifat sekunder, misalnya untuk melampiaskan gairah seksual kedua pasangan, untuk memcurahkan kasih sayang, untuk bertanggungjawab satu sama lain sebagai sebuah pasangan rumah tangga, serta menghindari perbuatan yang dilarang agama dalam hubungannya dengan lawan jenis. Dengan adanya perkawinan yang sah secara syariat, maka

14Muhammad Said Ramadhan al-Buthi, Barnāmij Dirāsat Qur'āniyah, Vol II (Ceramah tanggal 2 Januari 2008) http://www.naseemalsham.com/ar/Pages.php?page=Lessondetail\&pg_id=47079\&bk_id=45962\#

15Abd al-Ghaffar Abd al-Rauf, al-Qaḍāya al-Ijtimā'iyah fi Fikr Muhammad Sa`̄o Ramaḍan al-Būți, (Damaskus: dar al-Fikr, 2017), 198. 
tujuan-tujuan turunan (tabāiyah) ini memiliki hubungan erat dengan maqāṣid așliyah dalam perkawianan.16

Dalam konteks ini, maka upaya dalam menjaga terwujudnya tujuan perkawinan yang dasar (maqāșid așliyah) secara tidak langsung merupakan upaya untuk terlealisainya maqāșid tabāiyah itu sendiri. Akan tetapi tidak sebaliknya. Ulama kemudian membagai relasi maqāșid așliyah dan maqāșid tabāiyah dalam hukum keluarga Islam menjadi dua bagian: Pertama, merealisasikan maqasid tabaiyah sebagai penguatan (ta'kid) dalam maqāṣid aṣliyah. Dalam kondisi ini, tidak diragukan bahwa maqāșid tabāiyah tersebut sebagai bagian yang tidak terpisah untuk merealisasikan maqāșid așliyah. Misalnya, hubungan seksual suami-istri (maqāșid tabāiiyah) merupakan syarat utama terjadinya reproduksi dan pembuahan dalam proses kehamilan (maqasid asliyah). Kedua, posisi maqāssid tabāiyah justru bertentangan dengan terwujudnya maqāṣid așliyah.17

Oleh karena itu, dalam Islam dilarang adanya pernikahan dengan niat untuk menceraikan istrinya (al-zawāj bi niati alțalāq) dan nikah kontrak (nikah mut'ah) atau jenis pernikahan lainnya yang justru bertentangan dengan maqasid syariah itu sendiri seperti nikah dengan syarat diceraikan untuk dihalalkan bagi orang lain (hanya sebagai muhallil/penengah semata).

\section{Pandangan al-Buthi tentang Hukum Keluarga Berencana}

Sebelum membahas pandangan al-Buthi, akan dijelaskan program keluarga berencana. Atau dengan kata lain, cara pencegahan kehamilan yang menjadi pokok pembahasan artikel ini. Secara umum upaya pencegahan kehamilan dapat dibedakan menjadi dua bagian: bersifat temporer seperti 'azl dan alat kontrasepsi (kondom, pil, susuk, suntikan, alat kontrasepsi

16Hasan al-Sayyid Hamid Khattab, Maqāṣid al-Nikah wa Atharuhā: Dirāsah Fiqhiyah Muqāranah (Madinah: Tibah University, 2009), 141.

17Ibid. 142 
dalam rahim (AKDR), metode kalender hingga kondom) dan bersifat permanen seperti sterilisasi.18

Dalam konteks kajian ini, al-Buthi secara spesifik membahas tentang hukum mengikuti program pencegahan kehamilan yang bersifat temporer berdasarkan intervensi negara melalui program Keluarga Berencana. Hal ini karena hukum pencegahan kehamilan bersifat permanen hukumnya dilarang oleh agama karena bertentangan dengan tujuan syariat dalam pernikahan.

Yang perlu digarisbawahi adalah bahwa hukum melakukan pencegahan kehamilan atau pengaturan kehamilan ini merupakan sesuatu hak yang melekat kepada masing-masing pasangan suami-istri dalam rumah tangga. Itu sebabnya, kajian ini menitikbertakan pada bagaimana pengaruh intervensi negara dalam program KB secara massal kepada masyarakat tersebut memberikan pengaruh perubahan hukum dalam perspektif Islam.

Sebagaimana dikemukakan sebelumnya, bahwa al-Buthi secara spesifik menulis tentang topik ini dalam bukunya yang berjudul Mas'alah Tahdīd al-Nasl Wiqāyah wa Ilājān. Dalam pengantarnya, al-Buthi menggarisbawahi bahwa persoalan ini dapat ditilik pada dua optik, yakni analisis fikih (tahlīl al-fiqhi) dan analisis hukum positif ( $t a h ̣ l \bar{l} l$ al-qānūnì).

Dalam bahasa al-Buthi, program keluarga berencana adalah tahdìd al-nasl. Pada praktiknya, al-Buthi mengklasifikasikan pembatasan angka kelahiran anak dengan dua metode: wiqaiyah dan 'iläjiyah. Pada point yang pertama (wiqa'ilyah), yang dimaksud adalah segala upaya yang dilakukan pasangan suami istri untuk menghalangi terjadinya pembuahan saat berhubungan badan suami-istri, baik dengan 'azl atau metode lainnya (menggunakan alat kontrasepsi). Dengan kata lain, taḥdìd al-nasl bi al-asbāb al-wiq à'iyah merupakan tindakan pencegahan kehamilan yang dilakukan oleh kedua pasangan

18Rifdatus Sholihah, "Hukum Mencegah Kehamilan Perspektif Imam Ghazali dan Syekh Abdullah bin Baaz", Al-Hukama: The Indonesian Journal of Islamic Family Law, Volume 09, Nomor 01, (Juni 2019), 84-88. 
agar tidak terjadinya pembuahan yang bersifat temporer dengan berbagai metode misalnya minum pil $\mathrm{KB}$, suntik, kondom dan lainnya. Sementara metode kedua ('iläjiyah) yakni menghindari kehamilan dengan melakukan aborsi/pengguguran kehamilan. Pada artikel ini akan difokuskan pada tahdīd al-nasl bi al-asbāb al-wiqā'iyah.

Bagi al-Buthi, tahdid al-nasl dengan cara 'azl atau menggunakan alat kontrasepsi lainnya seperti kondom secara hukum Islam dapat dibenarkan.19 Karena hal tersebut merupakan rukhșah. Al-Buthi mengutip pendapat empat imam mazhab dalam fikih mulai Hanafiyah, Malikiyah, Syafi'iyah hingga Hanabilah. Yang menjadi perhatian adalah, bahwa kebolehan hukum tersebut dengan syarat atas persetujuan kedua pasangan, bukan sepihak dari suami semata.

Sebaliknya, jika pihak istri tidak berkenan suaminya melakukan 'azl atau penggunaan alat kontrasepsi lainnya yang dapat mencegah kehamilan, maka menurut Imam Malik, Abu Hanifah dan Ahmad Ibn Hambal hukumnya haram. Sementara di kalangan Syafi'iyah jika istrinya tidak menyetujui, maka hukumnya tidak haram menurut Imam al-Nawawi.20 Menyikapi kedua pendapat tersebut, al-Buthi lebih cenderung kepada pendapat Jumhur (Malik, Abu Hanifah dan Ahmad Ibn Hambal) dalam masalah azl tanpa persetujaun istri, yakni haram hukumnya.21

Al-Buthi menggarisbawahi bahwa kebolehan untuk melakukan taḥdìd al-nasl temporer baik dengan ‘azl maupun alat kontrasepsi ini karena adanya rukhșah di dalamnya yang bersifat personal di lingkup rumah tangga yang bersangkutan berdasarkan kemaslahatan pribadinya. Adapun hukum asal dari praktik tersebut tetap tidak diperbolehkan dalam Islam, karena

19Muhammad Said Ramadhan al-Buthi, Fiqh al-Sirah al-Nabawiyah Ma'a Mujaz li Tārikh al-Khilāfah al-Rasyīdah, Cet. XI (Damaskus: Dar al-Fikr, 2003), 207.

20Abd al-Ghaffar Abd al-Rauf, al-Qaḍāyā al-Ijtimā'iyah fi Fikr Muhammad Sa'̄̄d Ramaḍan al-Būṭi, (Damaskus: dar al-Fikr, 2017), 410.

21Muhammad Sa'id Ramadhan al-Buthi, Mas'alah Taḥdīd al-Nasl Wiqāyah wa Ilājān (Damaskus: Maktabah al-Farabi, 1988), 33. 
bertentangan dengan tujuan pokok dalam pernikahan.22 Karena rukhșah23 sangat bersifat personal, maka tidak boleh adanya intervensi dari pihak lain, misalnya pihak negara untuk mewajibkan program keluarga berencana dengan alat kontrasepsi tertentu yang bersifat temporer demi menekan angka pertumbuhan penduduk.

Berkaitan dengan anjuran program keluarga berencana massal atas intervensi pemerintah (negara) untuk mencegah kehamilan untuk menghambat laju ledakan penduduk sangat tinggi ini menurut al-Buti tidak dapat dibenarkan dalam Islam. Hal ini karena kebolehan taḥdìd al-nasl di atas harus berangkat dari pertimbangan kedua pasangan tanpa ada intervensi dari pihak manapun, termasuk dari pemerintah. Al-Buthi berargumen bahwa rukhșah itu selalu bersifat fardiyah (individu), bukan jama iyah (massal).

Kesimpulan hukum al-Buthi di atas dengan memberikan perbedaan hukum antara pencegahan kehamilan melalui 'azl atau dengan alat kontrasepsi lainnya atas intervensi pihak lain dan pencegahan kehamilan yang didasarkan pada niat pribadi kedua pasangan secara mandiri didukung oleh Abu Zahrah. Abu Zahrah berpendapat dalam bukunya demikian:24

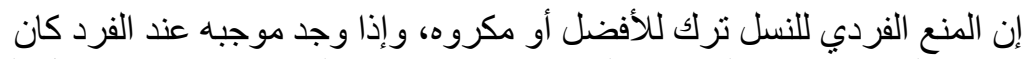

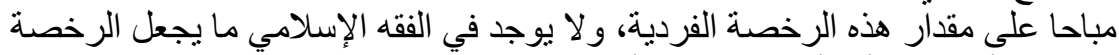

$$
\begin{aligned}
& \text { جماعية لأمة من الأمم أو لإقليم من الأقاليم فالرخهة الرحة دائما فردية. }
\end{aligned}
$$

Statemen di atas, menunjukkan bahwa Abu Zahrah juga mengamini bahwa kebolehan yang disebabkan oleh rukhsah bersifat personal, bukan bersifat massal. Pada konteks inilah

22Ibid, 25.

23Kondisi darurat dan adanya kemaslahatan pribadi yang dapat menjadi justifikasi melakukan program keluarga berencana dengan azl atau alat kontrasepsi lainnya adalah pertama, mempertimbangkan kesehatan pasangan suami istri, kedua, mempertimbangkan keselamatan istri disebabkan seringgnya hamil (sudah banyak anak), ketiga, alasan lemahnya ekonomi. Lihat, Ahmad al-Syarbasyi, al-Dīn wa Tanzīm al-Usrah (Kairo: dar al-Mathabi' 1966), 50.

24Muhammad Abu Zahrah, Tanżim al-Usrah wa Tanżìm al-Nasl (Kairo: Dar alFikr al-Arabi, 1976), 107. 
argumentasi Abu Zahrah dan al-Buti menemukan titik temunya. Dengan demikian, hukum pencegahan kehamilan secara umum (KB) hukumnya haram karena bertentangan dengan tujuan dalam pernikahan. Sebaliknya, taḥdīd al-nasl dibolehkan karena adanya pertimbangan-pertimbangan yang bersifat personal di antara kedua pasangan tanpa adanya intervensi dari luar, termasuk intervensi dari pemerintah.

Argumentasi lain yang dikemukakan al-Buthi tentang kebolehan tahdìd al-nasl harus dengan syarat bahwa tindakan tersebut berdasar pada kerelaan kedua belah pihak (suami-istri) tanpa adanya unsur paksaan atau arahan dari pihak luar. Karena bagi al-Buthi, sesuatu yang boleh dilakukan secara individual, terkadang tidak boleh dipaksakan untuk dilakukan secara kelompok (secara umum). Kaidah fikih ini disepakati oleh seluruh ulama mazhab.25

Al-Buthi menganalogikan masalah hukum tahdìd al-nasl dengan kasus hukum talak. Dalam Islam, talak adalah sesuatu yang diperbolehkan bagi setiap individu, saat dibutuhkan atau jika terdapat kemaslahatan yang diperoleh secara personal individu tersebut. Namun, seorang penguasa (negara) dalam hal ini tidak boleh memaksa masyarakat luas untuk menceraikan istri-istrinya, baik dengan paksaan, permintaan, maupun arahan. Dalam konteks inilah ada titik temu antara hukum talak dan taḥdìd al-nasl dengan ذ̇azl ataupun dengan alat kontrasepsi lainnya yang diintervensi pihak luar, termasuk pemerintah sekalipun.26

Bertolak dari uraian di atas, dapat dipahami bahwa pendapat al-Buthi tentang hukum tahdìd al-nasl. Al-Buthi memberikan catatan penting bahwa kebolehan tahdìd al-nasl melalui pencegahan kehamilan dengan cara 'azl atau alat kontrasepsi lainnya yang bersifat temporer tersebut dengan syarat adanya persetujuan kedua pasangan (suami-istri). Selain itu, dalam memutuskannya pun tidak dalam intervensi pihak

25Muhammad Said Ramadhan al-Buthi, Fiqh al-Sirah al-Nabawiyah Ma'a Mujaz li Tārikh al-Khilāfah al-Rasyīdah, Cet. XI (Damaskus: Dar al-Fikr, 2003), 208.

26Ibid, 208. 
lain, tetapi semata-mata hasil pertimbangan kedua belah pasangan (suami-istri) sebagai hukum yang bersifat personal karena kebolehannya termasuk kategori rukhșah bagi meraka. Adapun hukum asalnya, menurut al-Buthi adalah terlarang karena bertentangan dengan tujuan perkawinan itu sendiri, yakni mengembangbiakkan keturunan demi melanjutkan generasi umat manusia di muka bumi.

\section{Analisis Epistemologis Pemikiran al-Buthi}

Secara epistemologis, bahwa al-Buthi berpendapat bahwa adanya intervensi negara dalam program keluarga berencana massal menjadikan hukumnya terlarang (haram). Kesimpulan hukum ini berdasarkan pada dua argumen: Pertama, penalaran qiyasi, yakni al-Buthi menganalogikan hukum larangan program keluarga berencana massal yang diintervensi pihak negara dengan hukum persoalan talak. Kedua persoalan hukum tersebut antara kasus talak dan pencegahan kehamilan memiliki sifat yang sama, yakni kebolehannya sebagai rukhșah yang bersifat individual, bukan massal. Artinya, meskipun persoalan talak merupakan persolan yang dibolehkan dalam Islam, tetapi negara tidak dapat mengintervensi masyarakat untuk mengharuskan/menganjurkan untuk melakukan tindakan tersebut. Demikian halnya dengan hukum pencegahan kehamilan melalui metode 'azl atau alat kontrasepsi yang pada dasarnya dibolehkan oleh Islam, tetapi negara tidak boleh mengintervensinya.

Argumen kedua adalah kaidah ibāhah dengan pertimbangan maqāsidī. Pada dasarnya, dalam Islam hukum ibạhah (kebolehan) terbagi menjadi dua bagian: pertama, kebolehan yang sejalan dengan hukum dasarnya (hukm al-așl) dan memang mengandung di dalamnya kemaslahatan umum. Misalnya, hukum menikmati makanan yang bergizi yang tidak membahayakan tubuh. Hukum ibāhah pada masalah ini adalah berlaku untuk individu personal dan juga masyarakat umum secara massal (al-jamā'ah). Pada konteks ini, memungkinkan negara untuk mengintervsi demi untuk kepentingan publik dan terciptanya jaminan kesehatan bagi rakyat secara luas. 
Kedua, kebolehan (ibāḥah) yang tidak sejalan dengan hukum dasarnya (la yattafiq ma'a hukm al-aṣl min al- ibāhah alașliyah al-'ämmah), akan tetapi termasuk yang didispensasi (alafwu). Dengan kata lain, kebolehan yang disebabkan oleh faktor lain sesuai dengan kondisi personal-individu masing-masing. Dalam konteks ini, maka kebolehan hanya terbatas bagi orangorang yang memiliki kekhususan karena adanya sebab tertentu yang berhubungan dengan kondisi untuk mendapatkan dispensasi tersebut.

Jika dilacak lebih jauh, bahwa argumen yang dibangun oleh al-Buthi sejatinya mendapatkan legitimasi dari ulama klasik. AlSyatibi dalam kitabnya menulis demikian:

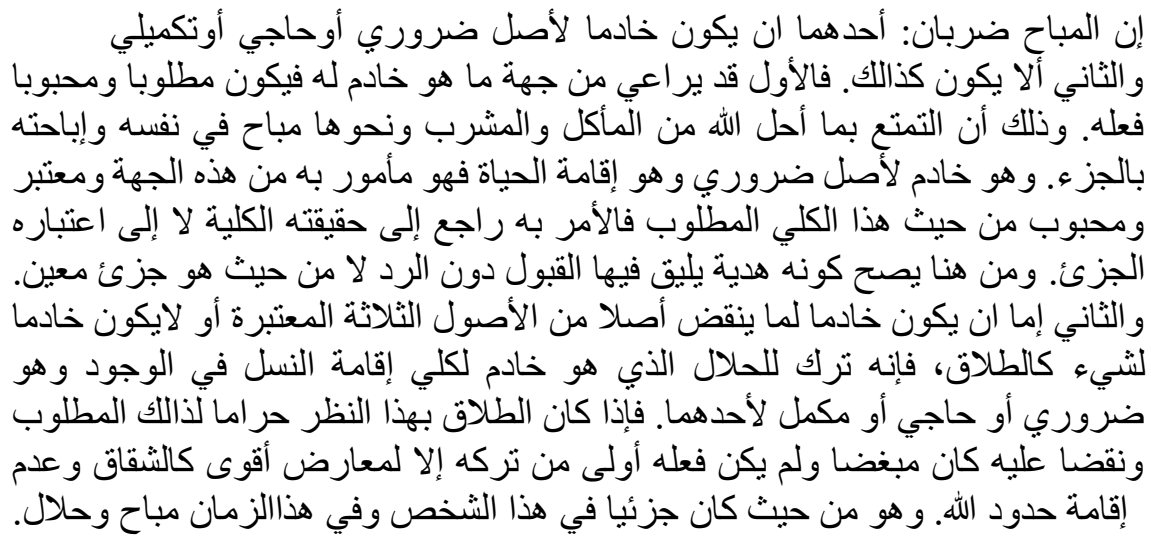

Dengan demikian, perkara yang dibolehkan karena adanya suatu perkara lain yang menyebabkan adanya keringanan tidak bisa dijadikan sebagai argumen untuk menyamaratakan hukum tersebut kepada pihak lain yang memiliki kondisi yang berbeda. Pada titik ini, sejatinya, pendapat al-Buthi mendapatkan legitimasi, sehingga hukum kebolehan program keluarga berencana atau upaya pencegahan kehamilan itu bersifat personal, dengan mempertimbangkan kondisi masing-masing pasangan suami istri dan atas persetujuan kedua belah pihak.

Selain itu, apa yang dikemukakan al-Buthi juga sejalan dengan kaidah fikih berikut:27

27Muhammad Sa'id Ramadhan al-Buthi, Mas'alah Taḥdīd al-Nasl., 22. 
Pandangan Al-Buthi Terhadap Hukum Mengikuti Program Keluarga Berencana

$$
\text { ليس كل ما هو مشروع للفرد مشرو عا للجماعة }
$$

Kaidah lainnya,28

$$
\text { لبس كل ما هو مرخص للفرد يكون مباحا للمجموع }
$$

Kedua kaidah di atas, secara sederhana dapat dipahami bahwa "Tidak semua yang disyariatkan untuk individu (fard) itu disyariatkan untuk kepentingan masyarakat umum (aljamā'ah)" dan "Tidak semua yang diberikan dispensasi untuk kepentingan individu itu berlaku dan dibolehkan bagi kelompok masyarakat lainnya (massal)." Dengan kata lain, bahwa terkadang sesuatu perkara yang dibolehkan Islam bagi individu tertentu (bi shakl juz'̄i), terkadang hal itu justru terlarang bagi orang-orang lainnya secara umum (bi shakl kullī). Kaidah ini merupakan kaidah pengecualian dari kaidah berikut ini:

$$
\text { تصرف الإمام على الرعية منوط بالمصلحة } 29
$$

Kendatipun pemimpin negara sebagai penguasa yang melindungi dan menjalankan otoritas kepemimpinannya untuk mewujudkan kemaslahatan rakyatnya, tetapi ada batas-batas tertentu dimana keputusan individu rakyatnya tidak dapat dicampuri oleh pemaksaan penguasa secara sepihak. Oleh karena itu, rakyat memiliki otoritas yang tidak dapat dicampuri oleh pihak manapun, termasuk negara.30 Pada titik ini, sama halnya dalam kasus pemaafan keluarga korban pembunuhan (maqtūl) dengan diganti diyat. Hak pemaafan ini merupakan otoritas keluarga yang tidak dapat dicampuri oleh pihak manapun. Bahkan, pihak penguasa (hakim) pun tidak dapat mengintervensi atau memaksa keluarga korban untuk memberikan pemaafan kepada pelaku tindak pidana pembunuhan tersebut agar mengalihkan kisas diganti dengan diyat.

Oleh sebab itu, ketika Islam (syariat) memberikan hak untuk menghentikan angka kelahiran (iqaf al-nasl) melalui program keluarga berencana hanya demi untuk kemaslahatan

28 Ibid.

29Lihat, Qutb al-Raisuni, Qāidah Tașarrufal-Imām ala al-Raiyyah Manūt bi alMașslaḥah wa Tațbīqatuhā al-Muāșirah fi al-Majāl al-Bi'̄i, Majallah Kulliyah alSyariah wa al-Dirasat al-Islamiyah, No. 29, (2011).

30Muhammad Sa'id Ramadhan al-Buthi, Mas'alah Taḥdìd al-Nasl., 19. 
kedua pasangan itu sendiri, meskipun bisa jadi secara sosial juga akan memberikan dampak secara luas bagi lingkungan sekitarnya. Pada konteks ini, memberikan otoritas kepada negara untuk mengintervensi rakyat terhadap persoalan yang dibolehkan secara agama justru merusak dan mensabotase kepentingan individu dan bertindak melampaui kewenangannya untuk menciptakan kemaslahatan dan perlingandungan hak-hak dasar rakyatnya secara umum.31 AlButi kemudian berkomentar demikian:32

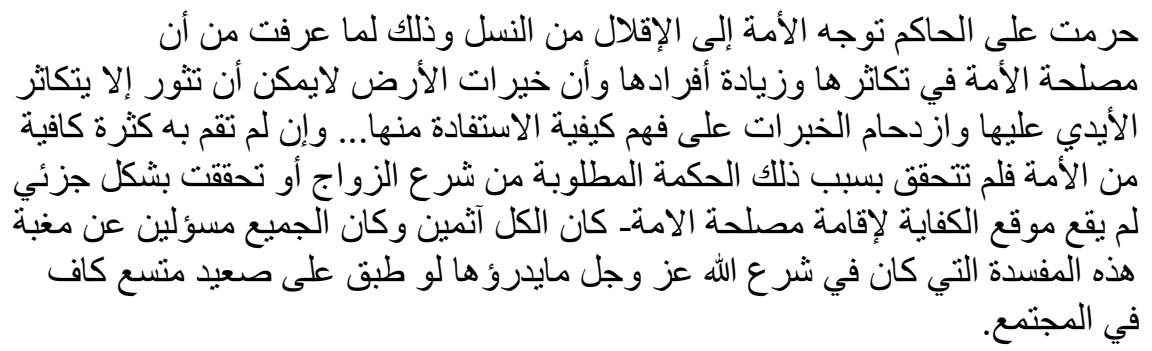

Dengan demikian, nalar qiyasi dan nalar maqāṣidī yang digunakan al-Buti dalam berijtihad hukum memberikan corak pemikiran baru yang selama ini dipahami secara general bahwa hukum kebolehan pencegahan kehamilan melalui program KB baik karena adanya intervensi pihak lain maupun niat kedua pasangan pribadi adalah sama. Al-Buthi memberikan dikotomi yang mendasar, bahwa harus dibedakan antara kedua kondisi tersebut.

Dalam konteks nalar qiyāsī, antara keluarga berencana (pencegahan kehamilan) dengan 'azl atau alat kontrasepsi (pil, suntik, kondom dan lainnya) dan hukum talak memiliki unsur kesamaan 'illat, sehingga menghasilkan kesimpulan hukum yang sama pula. Sementara nalar maqāṣidi tercermin dalam inti tujuan pernikahan adalah melahirkan keturunan (al-tanāsul) yang menjadi pertimbangan dalam penarikan kesimpulan hukumnya.

Oleh karena itu, tindakan yang bertentangan dengan tujuan pernikahan dalam rumah tangga ini hukumnya terlarang

31Muhammad Said Ramadhan al-Buthi, Fiqh al-Sirah al-Nabawiyah ., 22. 32Ibid, 62-63. 
kecuali ada sebab tertentu yang menjadikanya pasangan suami istri mendapatkan disepensasi (rukhșah). Termasuk larangan 'azl atau penggunaan alat kontrasepsi lainnya untuk mencegah kehamilan yang didasari intervensi pihak luar. Berbeda halnya, jika itu dilakukan berdasarkan pertimbangan tertentu untuk kemaslahatan pribadi kedua pasangan suami-istri dan atas kesepakatan kedua pasangan serta tanpa ada intervensi pihak lain, maka kondisi inilah memberikan peluang rukhșah bagi pasangan tersebut.

\section{Penutup}

Dari uraian sebelumnya, dapat disimpulkan bahwa pendapat al-Buthi tentang hukum pencegahan kehamilan melalui program Keluarga Berencana (KB) berdasarkan intervensi negara berbeda dengan hukumnya jika niat itu muncul dari kedua pasangan suami-istri tanpa intervensi dari pihak luar. Pandangan al-Buthi tentang hukum pencegahan kehamilan bersifat temporer melalui metode azl atau menggunakan alat kontrasepsi atas intervensi negara bertentangan dengan tujuan pernikahan sehingga tidak dibenarkan. Sebaliknya, jika tanpa intervensi negara itu dapat dibenarkan atas dasar rukhsah selama kedua pasangan saling setuju dan tidak dintervensi pihak lain.

Perbedaan di atas disebabkan oleh argumentasi yang dibangun oleh al-Buthi, yaitu: Pertama, bahwa dalam kaidah fikih disebutkan tidak semua yang dibolehkan syariat kepada individu tertentu juga dibolehkan kepada masyarakat umum lainnya. Kedua, argumen yang dibangun berdasarkan penalaran qiyasi dengan dianalogikan dengan hukum talak dalam pernikahan, dimana meskipun talak dapat dilakukan individu tertentu tetapi negara tidak boleh intervensi kepada masyarakat untuk melakukan talak secara massal.

Nalar epistemologis pemikiran al-Buthi bertumpu pada maqasid dalam hubungan keluarga Islam. Bagi al-Buthi, upaya pencegahan kehamilan melalui program Keluarga Berencana (KB) yang diintervensi oleh negara kepada rakyatnya bertentangan dengan tujuan utama pernikahan itu sendiri, yakni 
al-tanāsul (melahirkan generasi/keturunan), sehingga kebolehan yang bersifat individu tidak dapat dijadikan legitimasi untuk memaksa individu lain secara umum. Hal ini karena kebolehan KB merupakan rukhșah (keringanan) yang bersifat personal.

\section{Daftar Pustaka}

Abd al-Ghaffar Abd al-Rauf, al-Qaḍāyā al-Ijtimā'iyah fi Fikr Muhammad Sa'̄̂d Ramaḍan al-Būți, (Damaskus: Dār alFikr, 2017).

Ahmad al-Syarbasyi, al-Dīn wa Tanẓīm al-Usrah (Kairo: Dār alMathabi' 1966).

Basith, Abdul. "Konsep Istinbat Hukum Kontemporer Menurut Muhammad Sa'id Ramdhan al-Buthi, Jurnal Studi Islam dan Muamalah at-Tahdzib, Vol. 7, No. 2 (2019).

Al-Buthi, Muhammad Sa'id Ramadhan Hādhā Wālidi: al-Qișsah al-Kāmilah li Hayāt al-Syekh Mulla Ramaḍan Al-Būṭi min Wilādatih ila Wafätih, cet. IX (Damaskus: Dar al-Fikr, 2006).

, al-Lā Madhhabiyah, Akhtar Bid'ah Tuhaddid alSharī’ah al-Islämiyah, edisi revisi (Damaskus: Dar alFarabi, 2005).

- Mas'alah Taḥdīd al-Nasl Wiqāyah wa Ilājān (Damaskus: Maktabah al-Farabi, 1988). , Barnāmij Dirasāt Qur'āniyah, Vol II (Ceramah tanggal 2 Januari 2008) http://www.naseemalsham.com/ar/Pages.php?page=Le ssondetail\&p-g id $=47079 \& b k$ id $=45962 \#$ , Fiqh al-Sirah al-Nabawiyah Ma'a Müjaz li Tārikh alKhilāfah al-Rashīdah, Cet. XI (Damaskus: Dar al-Fikr, 2003).

Jasim Muhammad al-Mutawwi', Hadis al-Dzikrāyāt ma'a Faḍ̄lah al-Syaikh Muhammad Sa'Id Ramadan al-Büți, (https://www.youtube.com/watch?v=A5nmSE00zRw) diakses 2 April 2020

Khattab, Hasan al-Sayyid Hamid. Maqāṣid al-Nikah wa Atharuhā: Dirāsah Fiqhiyah Muqāranah (Madinah: Tibah University, 2009) 
Mufid, Moh. Nalar Ijtihad Fiqh Muhammad Sa'ìd Ramadhān alBūthi (Banjarmasin: Antasari Press, 2013). , "Kontribusi Muhammad Sa'id Ramadhan Al-Buthi dalam Pemikiran Hukum Publik Islam", Al-Jinayah: Jurnal Hukum Pidana Islam, Vol 4 No 1 (Juni 2018).

Muhammad Abu Zahrah, Tanżim al-Usrah wa Tanzīm al-Nasl (Kairo: Dar al-Fikr al-Arabi, 1976), 107.

Mujiati, Nanik dan Lukman Hakim. "Pemikiran al-Buthi tentang Problematika Dakwah", Jurnal Mediakita, Vol. 3, No. 1 (Januari 2019).

Mukit, Abdul. "Pendidikan Akidah: Telaah Pemikiran Muhammad Sa'id Ramadan al-Buthi", Jurnal Tawazun, Vol. 8 No. 1 (Januari-Juni 2015).

Al-Raisuni, Qutb Qā'idah Tașarrufal-Imām ala al-Ra'iyyah Manūt bi al-Mașlaḥah wa Tațbīqatuhā al-Muāșirah fi al-Majāl al$B i^{\prime} \bar{l}$, Majallah Kulliyah al-Syariah wa al-Dirasat alIslamiyah, No. 29, (2011).

Suherman, Gatot. "Poligami Kaum Elit Agama Islam: Menimbang Plus-Minus Praktik Poligami Kaum Elit Agama bagi Masyarakat", Istinbath: Jurnal Hukum Islam, Vol. 12, No. 2 (Desember 2013). 